\title{
An Outbreak of Infectious Coryza in an Emu farm at Tirupati, Andhra Pradesh, India
}

\author{
T.M. Nabeel Mohammad and B. Sreedevi* \\ Department of Veterinary Epidemiology and Preventive Medicine, College of Veterinary \\ Science, Sri venkateswara Veterinary University, Tirupati. AP, India \\ *Corresponding author
}

\section{Keywords \\ Infectious Coryza Emu farm, Avibacterium paragallium}

Article Info

Accepted:

12 February 2019

Available Online:

10 March 2019

\section{A B S T R A C T}

In the last few years, emu farming has gained more attention and popularity among the poultry farmers of southern India especially Andhra Pradesh. Infectious Coryza is primarily considered to be a disease of chicken even though the outbreaks have also been reported from guinea fowl and turkeys. An acute respiratory disease with high morbidity and mortality among emu chicks was reported from an emu farm located in the outskirts of Tirupati, Andhra Pradesh. The clinical signs observed were coughing, sneezing along with severe swelling of infra orbital sinus and adjacent paranasal sinuses suggestive of infectious coryza. The presence of Avibacterium paragallium in the samples was confirmed by PCR. In the best of our knowledge this is the first report of infectious coryza in emu birds.

\section{Introduction}

Infectious Coryza (IC) is an acute respiratory disease of poultry primarily affecting upper respiratory tract including the involvement of nasal passages, infra orbital and paranasal sinuses caused by bacterium Avibacterium paragallinarum.

Infectious Coryza is a cosmopolitan disease which has been reported from all around the world where chickens are raised including India. In the present study an outbreak of infectious coryza is reported from an emu farm.

\section{Materials and Methods}

\section{Sample collection}

About 18 Infra orbital sinus swabs were collected from the dead or sacrificed emu birds. The skin over the sinus was seared with hot spatula and incised with a sterile scalpel blade. The cotton swab was inserted into the sinus cavity. Gentle milking pressure was exerted on the sinus area and the mucus was forced from the nostril while collecting the samples from live birds. The mucus was collected with a sterile cotton swab. Six nasal swabs were also collected and aseptically collected swabs were soaked in $30 \%$ 
Glycerol-Phosphate Buffered saline. The samples were transported to the laboratory in ice packs at the earliest and stored at $-20^{\circ} \mathrm{C}$.

\section{Cultural examination of samples}

The samples were inoculated in to blood agar and chocolate agar. On blood agar, Staphylococcus aureus was cross streaked as a feeder culture for providing NAD which is essential for the growth of the Avibacterium paragallinarum. The plates were incubated at $37^{\circ} \mathrm{C}$ for 36 to 48 hours in candle jar.

\section{Antibiotic sensitivity test}

The antibiotic sensitivity test was performed in Muller Hinton agar supplemented with 1.5 $\%$ Sodium chloride, $1 \%$ inactivated, sterile chicken serum and NADH $(25 \mu \mathrm{g} / \mathrm{ml})$. The chicken serum and NADH were added to the medium at a temperature below $55^{\circ} \mathrm{C}$ and Kept for sterility check at $37^{\circ} \mathrm{C}$ for 24 hours before inoculation.

The antibiogram patterns of the samples tested were studied by using standard antibiotic discs (Himedia). The most commonly used antibiotics in poultry industry were selected for testing. Antibiogram of the samples were examined as per standard single diffusion technique according to Kirby-Bauer (Bauer et al, 1966) method modified by Clinical and Laboratory Standards Institute (CLSI). The antibiotic discs were placed on the media after inoculating with samples. The zone of inhibition was measured, recorded and interpreted according to Performance Standards for Antimicrobial Disc Susceptibility Tests, CLSI volume 31, No.1, January 2011.

\section{DNA extraction}

The standard phenol- chloroform method described by Sambrook and Russel (2001) was employed for the extraction of Avibacterium paragallinarum DNA with necessary modifications. Briefly, $567 \mu 1$ of sample was mixed with $30 \mu$ of $10 \%$ Sodium Dodecyl Sulphate (SDS) and $3 \mu \mathrm{l}$ of proteinase-K $(20 \mu \mathrm{g} / \mathrm{ml})$ and incubated at $37^{\circ} \mathrm{C}$ for one hour. Equal volume of phenol : chloroform solution was added and vortexed properly and centrifuged at $13000 \mathrm{rpm}$ for 10 minutes at $4^{0} \mathrm{C}$. The supernatant was taken out carefully and the phenol-chloroform extraction was repeated. Final supernatant was taken and mixed with 2.5 volume of chilled absolute ethanol and $1 / 10^{\text {th }}$ volume of $3 \mathrm{M}$ Sodium acetate $(\mathrm{pH}-5.2)$ and kept at $20^{\circ} \mathrm{C}$ for overnight. The tube was centrifuged at $13000 \mathrm{rpm}$ for 10 minutes, the pellet was washed with $70 \%$ chilled ethanol, air dried and dissolved in $30 \mu \mathrm{l}$ of TE buffer and stored at $-20^{\circ} \mathrm{C}$ until use.

\section{Oligonucleotide primers}

The primers used were described by Chen et al., (1996) and were synthesized by Eurofins Genomics India Pvt. Ltd., Bangalore.

Forward Primer - TGA GGG TAG TCT TGC ACG CGA AT - 23 bp

Reverse Primer - CAA GGT ATC GAT CGT CTC TCT ACT - 24 bp

\section{Polymerase Chain Reaction}

About $25 \mu \mathrm{l}$ reactions were used and the protocol was initially standardised for optimising the concentration of components of the reaction mixture in the PCR assay and then by varying the annealing temperature and cycling conditions as described by Chen et al., (1996) using Kyratec Supercycler SC200 thermocycler. The PCR product was stored at $-20^{\circ} \mathrm{C}$ until use. The Red Dye PCR Master mix (Genei, Bangalore) was used for PCR reaction which contains premixed 
dNTPs, Taq polymerase, $\mathrm{MgCl}_{2}$ and buffer at optimum concentrations. The gel loading dye was also incorporated to the master mix. The PCR reaction mix consisted of Red dye Master mix $12.5 \mu \mathrm{l}$, Forward primer $0.5 \mu \mathrm{l}$, Reverse primer $0.5 \mu \mathrm{l}$, Target DNA $3 \mu \mathrm{l}$, Molecular grade water $8.5 \mu 1$.

\section{Optimum conditions for PCR}

The DNA used for standardisation of protocol was extracted from Infectious Coryza Killed Vaccine (VentriBiologicals, Pune). The standardised protocol was used in PCR for field samples collected. Three $\mu$ l of target DNA along with $12.5 \mu \mathrm{l}$ of Red dye Master mix, $0.5 \mu \mathrm{l}$ each of primers and $8.5 \mu \mathrm{l}$ of molecular grade water were used in $25 \mu \mathrm{l}$ reaction mixture and PCR was carried out as per standardised cycling conditions. Denaturation was done at $94^{\circ} \mathrm{C}$ for 1 minute, annealing at $58^{\circ} \mathrm{C}$ for 1 minute and extension at $72^{\circ} \mathrm{C}$ for 2 minutes. An initial denaturation at $94{ }^{\circ} \mathrm{C}$ for 2.5 minutes and a final elongation at $72^{\circ} \mathrm{C}$ for 10 minutes were also performed

\section{Agarose gel electrophoresis}

Two percent agarose gel was prepared by boiling agarose in $50 \mathrm{ml}$ of $1 \mathrm{X}$ TAE buffer. After cooling to $50^{\circ} \mathrm{C}$, ethidium bromide was added to the agarose solution to a final concentration of $0.5 \mu \mathrm{g} / \mathrm{ml}$. The molten agarose was then poured in to the tray and the comb was fitted in to the slots on the tray. The comb was taken out after polymerisation and the gel was placed in a horizontal electrophoresis unit (Genei, Bangalore) filled with 1X TAE buffer up to a level of $1 \mathrm{~mm}$ above the gel surface. $10 \mu \mathrm{l}$ of the PCR product along with gel loading dye was loaded to the wells. The electrophoresis was performed at a voltage of $5 \mathrm{~V} / \mathrm{cm}$ of the gel. After sufficient migration, the gels were taken to gel documentation system (alpha Innotech) and the results were recorded.

\section{Results and Discussion}

An acute respiratory disease with high morbidity and mortality among emu chicks was reported from an emu farm located in the outskirts of Tirupathi. The clinical signs observed were coughing, sneezing along with severe swelling of infra-orbital sinus and adjacent para-nasal sinuses. The birds were unable to open their eyes due to pressure exerted by the mucus content of the infraorbital sinus and the eye balls were dislocated and pushed upwards from the socket (Fig. 1). The hard palate was pushed downwards to the buccal cavity due to high mucus content of sinuses. The birds were struggling to respire, eat and drink. Conjunctivitis, open mouth condition was noticed.

The signs were first observed in 15 days old birds which were arrived as a new stock 10 days before the outbreak and spread the disease to 1 month and 2 month old chicks. The adult birds(18 month old) were found unaffected (Table 1). Severe inflammation of upper respiratory tract and paranasal sinuses, accumulation of copious amounts of mucus, air sacculitis with thickening of air sacs, fatty liver were noticed during PM examination. Similar findings were reported by several workers in chickens (Blackall and Soriano 2005).

The blood agar plates inoculated with suspected samples were incubated at $37^{\circ} \mathrm{C}$ in a candle jar for 36-48 hours showed multiple colonies of different sizes and morphology along the line of streaking. The characteristic, satellite growth of Avibacterium paragallinarum was not clearly distinguishable due to the overgrowth of some other bacterial colonies. The smears made of suspected colonies were found to have gram negative short rods. Avibacterium paragallinarum colonies mixed with other colonies were identified by their typical tiny 
dew drop appearance, mucoid or rough colonies. The suspected colonies obtained on blood agar were sub cultured on enriched chocolate agar for obtaining Avibacterium paragallinarum in pure culture. It was found very difficult to isolate Avibacterium paragallinarum in pure culture. Avibacterium paragallinarum is a delicate organism that can be readily killed by heat and die rapidly in culture and storage unless freeze dried or stored at minus $70^{\circ} \mathrm{C}$ (Hirsh and Birbestein 2004).

The results of the antibiotic sensitivity test showed that the samples were sensitive to Gentamycin, Oxytetracyclin, Ciprofloxacin and Chloramphenicol. Intermediary sensitive to Sulfa methoxazole, Co-trimoxazole, Pefloxacin, Doxycycline and Neomycin and resistant to Enrofloxacin, Levofloxacin, Erythromycin, Streptomycin and Ampicillin. Treatment with levofloxacin, enrofloxacibromhexine combination was found to be ineffective. The reports of existence of drug resistant genes to Streptomycin, Sulphamethoxazole, Kanamycin, Neomycin, Tetracycline and Ampicillin in both the plasmids and chromosomes of Avibacterium paragallinarum (Hsu et al, 2007; Byarugaba et al, 2011, Nabeel Mohammad, 2016) points towards importance of performing antibiotic sensitivity test before the treatment for infectious coryza.

The difficulties associated with conventional culture method and biochemical characterization of infectious coryza made the molecular technique, PCR attractive. The DNA was extracted as from Infectious Coryza Killed Vaccine, Ventribilogicals, Pune and dissolved in TE buffer. Three $\mu$ of dissolved DNA was used as target in PCR experiment. Initially PCR reaction was held at $94^{\circ} \mathrm{C}$ for 2.5 minutes for denaturation. Then 30 cycles of denaturation at $94^{\circ} \mathrm{C}$ ( 1 minute), annealing at $58^{\circ} \mathrm{C}$ ( 1 minute), extension at $72^{\circ} \mathrm{C}(2$ minute) was carried out. The reaction was held at $72^{\circ} \mathrm{C}$ for 10 minute for final elongation before bringing to the final holding temperature of $4^{0} \mathrm{C}$. The size of the amplified product was analysed by agarose gel electrophoresis using standard DNA molecule size marker. The size of the amplified product was $500 \mathrm{bp}$, which was the size of the amplicon defined by selected primers. No amplification was observed in negative control indicating that amplicon was specific to bacteria Avibacterium paragallinarum.

The standardized PCR protocol was used to screen the field samples. The results of the PCR tests were evaluated by agarose gel electrophoresis. Out of 18 infra orbital sinus swabs and 6 nasal swabs screened, 13 $(72.2 \%)$ and $2(33.3 \%)$ respective samples showed positive results for infectious coryza in PCR (Fig. 2). The reports of successful application of PCR for the diagnosis of infectious coryza were also reported by other workers from chicken (Kaur et al, 2004; Byrugaba et al., 2007; Chukiatsiri et al, 2010; Nabeel Muhammad, 2015).

Table.1 Morbidity and Mortality percentages in different age groups

\begin{tabular}{|l|c|c|c|}
\hline Age & No of birds affected & morbidity & mortality \\
\hline 15 days & 134 & $70(52.2 \%)$ & $61(45.5 \%)$ \\
\hline 1 month & 25 & $13(52 \%)$ & $11(44 \%)$ \\
\hline 2 months & 25 & $12(48 \%)$ & $10(40 \%)$ \\
\hline
\end{tabular}


Fig.1 Infectious coryza in emu birds - swollen infra-orbital sinuses
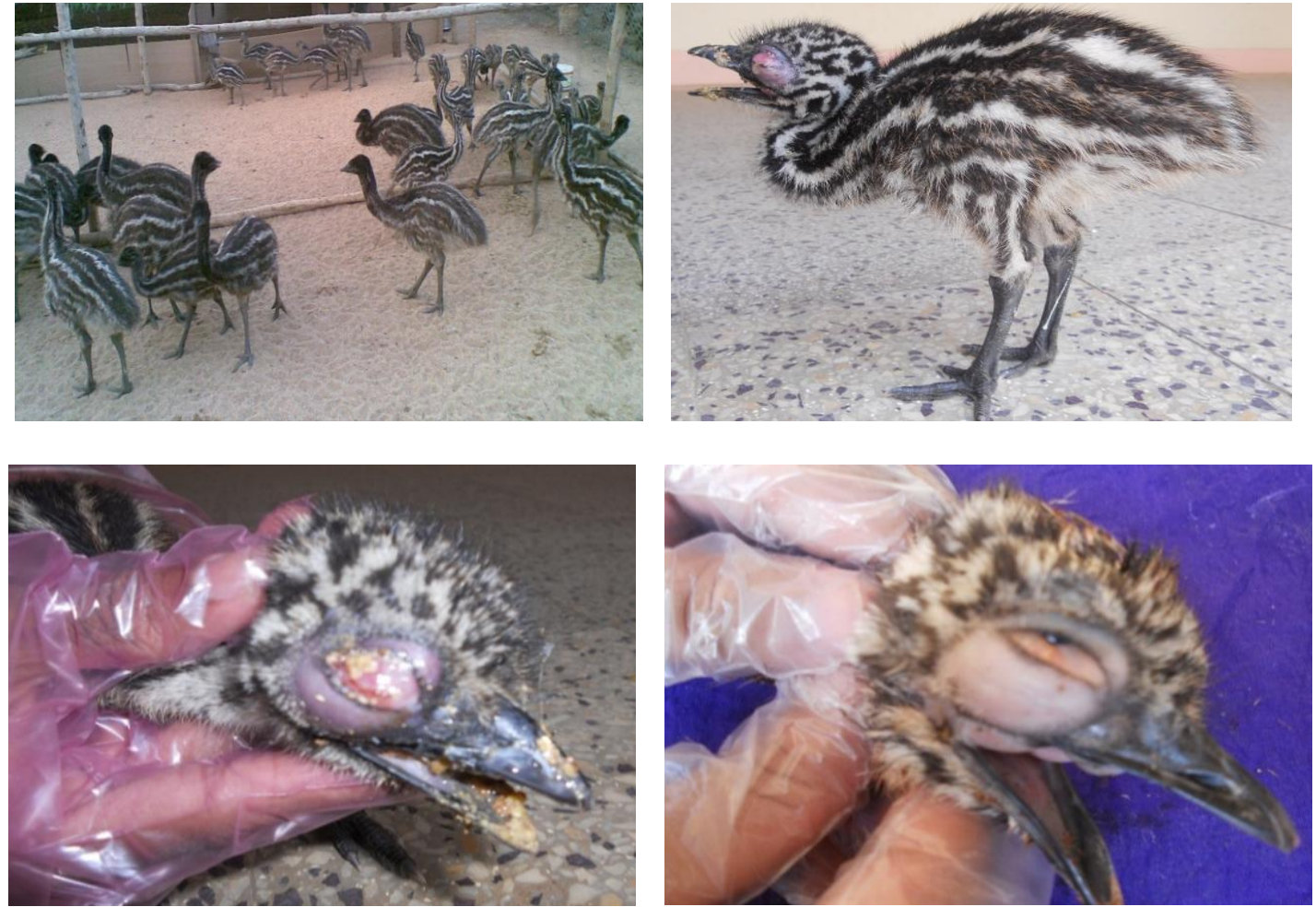

Fig.2 Polymerase chain reaction - showing 500 bp product of Avibacterium paragallinarum from vaccine and emu samples

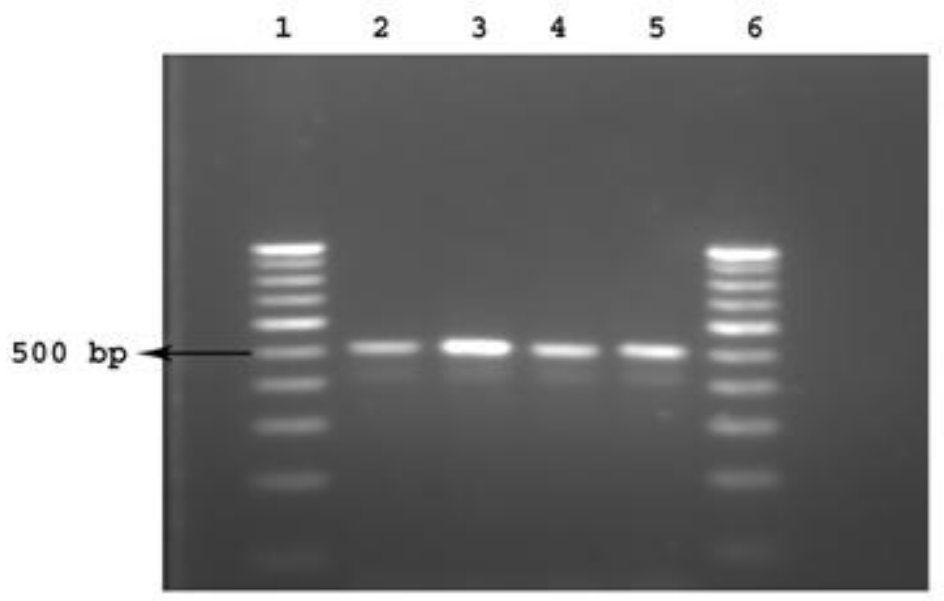

The PCR was as an easier and rapid diagnostic tool for infectious coryza and found to be highly sensitive while screening the field samples. In the present study an outbreak of infectious coryza was suspected in an emu farm and the presence of Avibacterium paragallinarum was confirmed by polymerase chain reaction. Reports on infectious coryza infection in emu have not yet been published anywhere and this could be the first report. Huge investment and 
high cost of individual bird makes infectious coryza in emus more significant.

It is concluded that, in the present study an outbreak of infectious coryza was suspected in an emu farm and the presence of Avibacterium paragallinarum was confirmed by polymerase chain reaction. Reports on infectious coryza infection in emu have not yet been published anywhere and this could be the first report. Huge investment and high cost of individual bird makes infectious coryza in emus more significant.

\section{References}

Bauer, A. W., Kirby, W. M., Sherris, J. C. and Truck, M. $1966 . \quad$ Antibiotic susceptibility testing by a standardised single disc method. American Journal of Clinical Pathology., 45: 493-496.

Blackall, P. J. and Soriano, V. E. 2005. Infectious coryza and related bacterial infections. In: Saif Y M (Ed.) Diseases of poultry. Iowa state university press: 789-803.

Byarugaba, D. K., Minga, U. M., Gwakisa, P.S., Katunguka, R. E., Bisgaard, M., Christensen, H. and Olsen, J.E. 2007. Investigations on the occurrence of Avibacterium paragallinarum infections in Uganda. Avian Dis., 51:534-539.

Byarugaba, D. K., Minga, U. M., Gwakisa, P. S., Katunguka, R. E., Bisgaard, M., Christensen, H. and Olsen, J. E. 2011. Demonstration of antibiotic resistance genes strA, blaTEM, tetA, tetC and sul2 in Avibacterium paragallinarum. Afr. J. Microbiol. Res., 22: 3624-3627.

Chen X., Miflin. J. K., Zhang, P. and Blackall, P. J. 1996. Development and application of DNA probes and PCR tests for
Haemophilus paragallinarum. Avian Dis., 40:398-407.

Chukiatsiri, K., Chotinun, S. and Chansiripornchain, N. 2010. An outbreak of Avibacterium paragallinarum serovar $\mathrm{B}$ in a Thai layer farm. Thai Veterinary Medical Journal., 40: 441-444.

Hirsh, D. C. and Biberstein, E. L. 2004. Pasteurellaceae: Haemophilus and Histophilus. In: Hirsh D C, Maclachlan $\mathrm{N} \mathrm{J}$ and Walker R L. (Eds.) Veterinary Microbiology $2^{\text {nd }} \quad$ Ed. Blackwell publishing: 95-99.

Hsu, Y. M., Sheih, H. K., Chen, W. H., Sun, T. Y. and Shiang, J. H. 2007. Antimicrobial susceptibility, plasmid profiles and hemocin activities of Avibacterium paragallinarum strains. Vet Microbiol., 124: 209-218.

Kaur, J., Sharma, N. S., Gupta, K. and Singh, A. 2004. Epidemiological studies on infectious coryza in chickens in northern India. Indian J Anim Sci., 74: 462-465.

Nabeel Muhammad, T. M. and Sreedevi, B. 2015. Detection of Avibacterium paragallnarum by polymerase chain reaction from outbreaks of Infectious coryza of poultry in Andhra Pradesh. Vet world., 8(1): 103-108.

Nabeel Muhammad, T. M., Sreedevi, B. and Shobhamani, B. 2016. Antibiotic sensitivity pattern of Avibacterium paragallinarum from Infectious coryza in Andhra Pradesh. The Indian Vet J., 93(02): 51-53.

Sambrook, J. and Russel, D.W. 2001. Molecular cloning: A laboratory Manual. Cold Spring Harbour Laboratory press: Volume 1, 2 and 3.

\section{How to cite this article:}

Nabeel Mohammad, T.M. and Sreedevi, B. 2019. An Outbreak of Infectious Coryza in an Emu farm at Tirupati, Andhra Pradesh. Int.J.Curr.Microbiol.App.Sci. 8(03): 1430-1435. doi: https://doi.org/10.20546/ijcmas.2019.803.167 